\title{
The role of aggression in the relationship between grandiose narcissistic traits and interpersonal style: University students in Turkey
}

\author{
Büyüklenmeci narsisistik kişilik özellikleri ile kişiler arası tarz arasındaki \\ ilişkide saldırganlığın aracı rolü: Türkiye'deki üniversite öğrencisi \\ örneklemi
}

Neslihan Arıcı Özcan1, Ömer Erdem Kocak2, Reyhan Arslan ${ }^{3}$

${ }^{1}$ Assis. Prof., Istanbul Medeniyet University, Faculty of Health Sciences, Department of Social Work, Istanbul

${ }^{2}$ Assis. Prof., Istanbul Medipol University, Faculty of Business and Administration, Department of Business, Istanbul

${ }^{3}$ Res. Asis.,Istanbul Medipol University, Faculty of Education, Department of Guidance and Psychological Counseling, Istanbul

\section{SUMMARY}

Objective: The aim of this study is to investigate the role of aggression in the relationship between grandiose narcissistic personality characteristics and negative interpersonal relationship style. Grandiose narcissistic features include overconfidence, high self-esteem, dominance and exploitative interpersonal style, expectation of attention and admiration from others, and aggressive attitudes and behaviors through the concept of threatened egotism. Method: In this study, 577 university students participated from different departments. Narcissistic Personality Inventory for measuring the grandiose narcissistic features, Buss-Perry Aggression Questionnaire for measuring the aggression, Interpersonal Style Scale and demographic form are used. Research model was tested with structural equation modeling using Amos 21 software. In this process sub-dimensions of interpersonal relationship style are used as manifest variable while five indicators for grandiose narcissistic features and 3 indicators for aggression are used as latent variables. Results: The primary analysis of the study indicated that goodness-of-fit statistics show that the data fit well to the model $\left(x^{2}\right.$ : 180.801, df: 54, CFI: .976, TLI: .959, GFI: .958, RMSEA: .064, SRMR: .051). According to the results, aggression mediates the relationship between grandiose narcissistic personality characteristics and negative interpersonal communication styles (x²: 259.405, df: 65, CFI: .963, TLI: .948 GFI: .941, RMSEA: .072, SRMR: .055). Discussion: The significant mediation effect of aggression implies that narcissistic features bring with aggression toward other people that ultimately lead to getting in contact with people in a negative manner.

Key Words: Aggression, narcissism, grandiosity, interpersonal style, interpersonal relationships

(Turkish J Clinical Psychiatry 2018;21:341-350)

DOI: $10.5505 / \mathrm{kpd} .2018 .85547$

\section{ÖZET}

Amaç: Bu çalışmanın amacı, üniversite öğrencilerinde büyüklenmeci narsistik kişilik özellikleri ile olumsuz kişiler arası ilişki tarzı arasındaki ilişkide saldırganlığın aracı rolünü incelemektir. Büyüklenmeci narsistik kişilik özellikleri, kendine aşırı güven, baskınlık, sömürücü ilişki tarzı, beğenilme beklentisi ve benlik saygısı tehdit edildiğinde ortaya çıkan yoğun öfke ve düşmanca tutumları içermektedir. Yöntem: Araştırmaya 577 üniversite öğrencisi katılmıştır. Veri toplamak amacıyla Narsistik Kişilik Envanteri, Buss Perry Saldırganlık Ölçeği ve Kişiler Arası Tarz Ölçeği kullanılmıştır. Çalışmada değişkenler arası ilişkiler ve saldırganlığın aracı değişken etkisi eş zamanlı olarak Amos 21 yazılımıyla yapısal eşitlik modellemesi kullanılarak test edilmiştir. Çalışmada Kişiler Arası Tarz ölçeğinin tüm alt boyutları gözlenen değişken olarak ele alınırken, Buss Perry Saldırganlık Ölçeğinin üç alt boyutu ile Narsistik Kişilik Envanterinin beş alt boyutu gizil değişken olarak değerlendirilmiştir. Bulgular: Analizler sonucunda ölçüm modeli uyum değerleri, modelin değişkenler arası analiz yapmak için uygun olduğunu göstermiştir ( $x^{2}:$ 180.801, df: 54, CFI: .976, TLI: .959, GFI: .958, RMSEA: .064, SRMR: .051). Sonuçlar, saldırganlığın, büyüklenmeci narsistik kişilik özellikleri ile olumsuz kişiler arası tarz arasındaki ilişkide aracılık etkisi gösterdiğini ortaya koymaktadır (x2: 259.405, df: 65, CFI: .963, TLI: .948 GFI: .941, RMSEA: .072, SRMR: .055). Sonuç: Aracılık etkisi, narsistik özelliklerin saldırgan davranışları beraberinde getirdiğine, bunun sonucunda da işlevsel olmayan ilişki kurma biçimlerinin ortaya çıktığına işaret etmektedir.

Anahtar Sözcükler: Saldırganlık, narsisizm, büyüklenme, kişilerarası tarz, kişiler arası ilişkiler 


\section{INTRODUCTION}

Narcissism, a character defect recognized as far back as ancient times, has recently grown in popularity as a subject of clinical, social-personality, and industrial-organizational psychological study $(1,2)$. This increasing interest in narcissism has brought a significant imbalance between theory construction and the production of empirical data to light (3).

Narcissism is defined as a relatively permanent character trait encompassing grandiosity, lack of empathy, and inflated self-appraisal (4). In terms of social-personality psychology and clinical psychology, narcissism is widely conceptualized as a trait or a personality disorder, respectively (5). Clinical psychologists view narcissism as taxon in clinical settings. They also use clinical ratings and interviews in order to assess narcissism. Contrarily, social-personality psychologists judge narcissism to represent a dimension of the non-clinical population and utilize self-report measures in their assessment of the phenomenon (6). However, much research conducted on both the clinical and nonclinical population indicates that both these conceptualizations share many similarities. For starters, both schools of thought use the same measures in their assessment of narcissism $(5,7,8)$.

Moreover, a number of theories and explanations have been enlisted in order to account for narcissism. It is commonly postulated that narcissism is divided in two subtypes; grandiose and vulnerable $(6,9,10,11)$. In this study, grandiose narcissism was taken into higher consideration due to fact that the literature accounts for a significant correlation with the variables (aggression and interpersonal style) which remain the focus of this study. Grandiose narcissism generally correlates with overconfidence, high self-esteem, dominance and exploitative interpersonal style, expectation of attention and admiration from others, and aggressive attitudes and behaviors through the concept of threatened egotism $(12,13,14,15,16,17)$.

Furthermore, grandiose narcissism carries with it a number of interpersonal problems due to its egocentric nature (18). People with grandiose narcissism use self-enhancement strategies to manage their self-esteem, and when these strategies are threatened by others, then the latter are instantly devalued $(9,18)$. In other words, those who display grandiose narcissism necessarily engage in a domineering and exploitative interpersonal style.

In grandiose narcissism, aggression is triggered when the self is perceived as under threat (17). As literature on the subject largely concurs, grandiose narcissism correlates with reactive (provoked/ impulsive) and proactive reaction (unprovoked/planned) $(19,20)$. Bushman and Baumeister (21) have stated that people with grandiose narcissistic personality characteristics show significantly more physical aggression than others, even when unprovoked. Another study shows that grandiose narcissism is a strong predictor of aggressive behavior (22). Ronnigstam (23) indicates that people with grandiose narcissistic personality characteristics exhibit externalizing behaviors such as fighting, arguing, cursing, threatening, and bullying that bring about inappropriate communication styles in their relationships. Similarly, Campbell and Foster (24) state that people with grandiose narcissistic personality characteristics generally lack empathy for other people and are tend to exploit and blame them. Thus, it is agreed that there is a significant correlation between aggression and grandiose narcissism (13). In line with such conclusions, it can be said that explicit aggression is apparently seen in grandiose narcissism.

This study aims to investigate the role of aggression in the relationship between grandiose narcissism and interpersonal problems. To this end, the definition of aggression laid out in Buss Perry's aggression scale (25) will be utilized, thus incorporating physical aggression, verbal aggression, anger, and hostility.

Furthermore, aggression and interpersonal problems are dramatically increased in the adolescent phase $(26,27)$. Aggression and interpersonal problems among youths can generally stem from the youth's identity formation process. Adolescents are more egocentric, exploitative, and attention seeking because they lack a fuller awareness of their thoughts, feelings, and behavior in both a social 


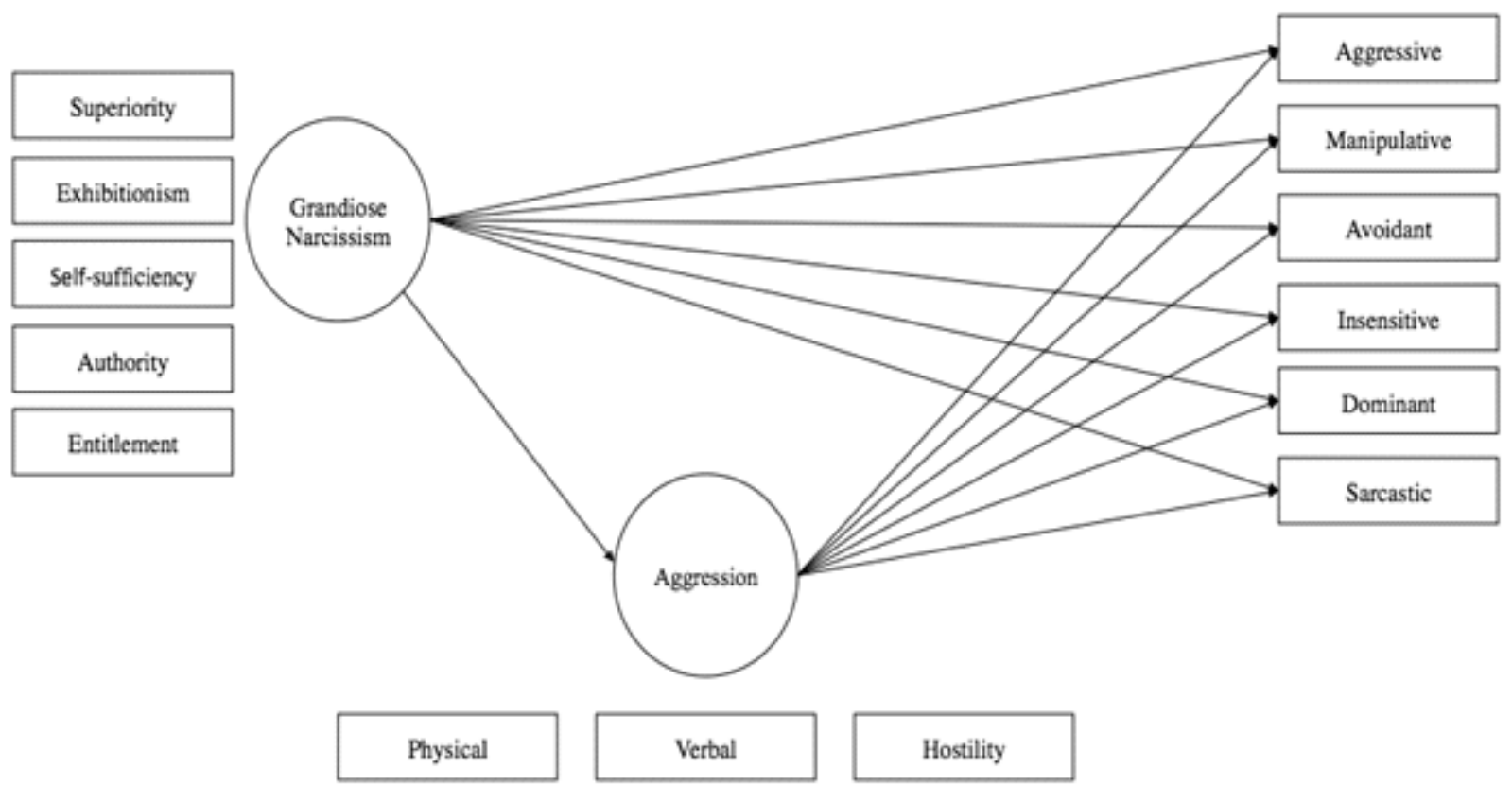

Figure 1. Research model

and interpersonal context (28). Evans, Heriot, and Friedman (29) note that adolescents having high level of aggression can show low level of empathy in interpersonal relationship, and this can be associated with narcissism. Some scholars $(30,31)$ indicate that aggression in children and adolescents is a predictor of narcissism as a conduct problem. Furthermore, narcissism is more prevalent between young individuals, especially in 20-29 years old persons (32). Given that the trait appears to embed itself in individuals in this age group, university students have been chosen as the test subject to investigate the role of aggression in the relationship between grandiose narcissism and interpersonal problems that are operationally defined as negative interpersonal relationship styles.

\section{Aims of the Study}

The aim of study is to examine the role of aggression in the relationship between grandiose narcissism and interpersonal problems.

\section{Hypothesis}

H1: Aggression mediates the relationship between grandiose narcissism and anger communication style.
H2: Aggression mediates the relationship between grandiose narcissism and dominant communication style.

H3: Aggression mediates the relationship between grandiose narcissism and insensitive communication style.

H4: Aggression mediates the relationship between grandiose narcissism and avoidant communication style.

H5: Aggression mediates the relationship between grandiose narcissism and manipulative communication style.

H6: Aggression mediates the relationship between grandiose narcissism and sarcastic communication style.

\section{METHOD}

\section{Participants}

The study took data from 577 psychology students from the Psychology, Counseling, and Medical Science departments of Istanbul Medipol University. The mean of participants' age was 20, 
with $30 \%$ representing males. The vast majority of participants were first-year and second-year students, $45 \%$ and $27 \%$, respectively. $15 \%$ of participants had been diagnosis with at least one psychiatric disorder during their lifetime, and $20 \%$ of these had undergone some form of therapy, medication program, or both.

\section{Measures}

The study utilizes the Narcissistic Personality Inventory (NPI) as a means of measuring grandiose narcissism, the Buss-Perry Aggression Questionnaire (BAQ) for measuring aggression, as well as the Interpersonal Style Scale (ISS) and demographic form.

Narcissistic personality inventory (NPI) This scale developed by Ames, Rose, and Anderson (33) was adapted into Turkish by Atay (34), and measures narcissistic personality traits. The scale consists of 16-items of dichotomous type. The reliability and validity of the original scale has been proven by five separate studies. The Cronbach alpha among university student sample measured .72 . The scale represents six factors (superiority, exhibitionism, selfsufficiency, authority, entitlement, exploitativeness). The first unrotated factor ranged from .13 to .66. The first factor explains 19.9 percent of variance. The mean of internal consistency of the original scale was found to be .67 (33). The reliability of the Turkish version of the scale is .62. The principal components of exploratory factor analysis show that items are fit in the original form, and that six factors have been observed. Upon analysis, a measuring device consisting of 16 items explaining 60,8 $\%$ of the total variance has been obtained. The exhibitionism factor explains $17,19 \%$, of the total variance; the superiority factor explains $10,10 \%$, of the total variance; the authority factor explains 9.23 $\%$ of the total variance; the entitlement factor explains $8,75 \%$ of the total variance; the exploitativeness explains $7.97 \%$ of the total variance; the self-sufficiency factor explains $7,59 \%$ of the total variance. In this study, internal consistency of the scale is found .86 and AVE is .51. The exploitativeness scale factor loading was below .50. Thus, this factor was excluded from the study.
Buss-Perry aggression questionnaire This scale consists of 29 items with 5 Likert type options developed by Buss and Perry (25), and was adapted into Turkish by Demirtaş Madran (35). The Turkish version of the scale coincides with that of the original form. The minimum score is 29 and maximum score is 145 . Two reverse items are included. The Turkish version also contains four factors (physical aggression, verbal aggression, anger and hostility) explaining $41.4 \%$ variance. The internal consistency of the original form Cronbach ? is .89 for total, .85 for physical aggression, .72 for verbal aggression, .83 for anger and .77 for hostility. The internal consistency of the Turkish version of the scale Cronbach $\alpha$ is .85 for total, .78 for physical aggression, .48 for verbal aggression, .76 for anger and .71 for hostility. The test-retest reliability coefficient of the Turkish version of the scale with an interval of 4 weeks is .97 for total, .98 for physical aggression, .82 for verbal aggression, .85 for anger and .85 for hostility. The concurrent validity of the Turkish version of the scale with sub-dimension of anger behaviors of Multi-dimensional Anger Scale (36) is $0.49(\mathrm{p}<.01)$. In this study, internal consistency of the scale was found as .77 and average variance extracted (AVE) was .49. We excluded anger dimension in order to avoid interference with communication styles. Although the threshold for AVE is $.50, .49$ is close enough that we deemed it better to exclude this AVE score.

Interpersonal style scale This scale consists of 60 items with 5 Likert type options, is developed by Şahin et al. (37). The scale aims to measure interpersonal communication style. The maximum score shows negative interpersonal style. The factor analysis shows six factors; namely, dominance, avoidance, aggressiveness, insensitivity, manipulation, and sarcasm. The Cronbach alpha reliability coefficients for factors are varied between .88 and .67. The reliability coefficient of total items is .93 . The significant correlation between the total score of the scale and the Brief Symptom Inventory (BSI) is .40 $(\mathrm{p}<0.01)$. A significant correlation between the sub-dimensions of the scale (BSI) ranges from .49 to $.17(\mathrm{p}<0.01)$. In this study, internal consistencies of the six subscales ranges between .71 and .90. Also, the internal consistency of the total scale was found as .85 with an AVE of .51. Six negative communication styles were constructed as manifest 
variables in the study.

\section{Ethics Statement}

Ethical permission to conduct the study was taken from the Social Sciences Ethics Committee of Istanbul Medipol University. After ethical approval was granted, the process of data collection was begun. Participants initially received a written informed consent form in which they were informed about the study and confidentiality was assured. The participants who acknowledged that they voluntarily participate in the study were given the scales. The participants were not required to give any personal information and were told that they could pass up the study if they no longer wished to continue or felt uncomfortable with the questions.

\section{Procedure}

Data was collected from students of Istanbul Medipol University in Istanbul, Turkey's largest city. The snowball method was used in the sampling process. After ethical permission was obtained, all instruments were presented to participants through paper-pen format. It took approximately 10-15 minutes to fill in all the questionnaires. Participation was on a voluntary basis. The process of data collection lasted for two months.

\section{Statistical Analysis}

Prior to statistical analyses, data was examined for accuracy of information and missing values. Then, outliers detected according to $\mathrm{z}$ scores exceeding \pm 3.29 were removed from the data. After that, normal distribution of data was tested and normality was assured. The Statistical Package for the Social Sciences (SPSS) version 23 was utilized in order to analyze the associations between the variables of the study. Research models were tested using Structural Equation Modeling (38) on Amos 21 software. The model fit was assessed depending on several goodness-of-fit indices. These are ChiSquare statistics divided by the degree of freedom $\left(\mathrm{x}^{2} / \mathrm{df}\right)$; comparative fit index (CFI), Tucker-Lewis coefficient (TLI), goodness of fit index (GFI), root mean square error of approximation (RMSEA) and the standardized root mean square residual (SRMR) $(39,40)$. In order to test the mediation effect, the bootstrap method suggested by Preacher and Hayes (41) was used.

In this study, an item-parceling process was utilized, as each of scale accounts for various questions and dimensions (42). In line with this process, the mean of each sub-dimensions were taken and evaluated as manifest variables of related latent variables. Finally, five indicators for grandiose narcissism were attained, along with four indicators for aggression latent variables.

\section{RESULTS}

The means, standard deviations and correlations for the research variables are shown in Table 1 . Bivariate correlations indicate that all variables are inter-correlated around middle levels.

\section{Measurement Model}

Before hypothesis testing, we examined convergent validity $(43,44)$ by examining the item loadings and their associated $t$-values. All of the indicators must be greater than 0.40 (45), indicating that convergent validity has been achieved. All t-values and

Table 1. The Means, Standard Deviations, and Correlations for the Variables

\begin{tabular}{|c|c|c|c|c|c|c|c|c|c|c|}
\hline \multicolumn{11}{|c|}{ Correlations } \\
\hline & Variables & $\mathrm{M}$ & $\mathrm{SD}$ & 1 & 2 & 3 & 4 & 5 & 6 & 7 \\
\hline 1 & incs aggressive & 2.54 & .948 & 1 & & & & & & \\
\hline 2 & incs manipulative & 2.22 & .776 & $.45^{*}$ & 1 & & & & & \\
\hline 3 & incs avoidant & 2.12 & .738 & $.45^{*}$ & $.67^{*}$ & 1 & & & & \\
\hline 4 & incs insensitive & 1.24 & .578 & $.28^{*}$ & $.45^{*}$ & $.59^{*}$ & 1 & & & \\
\hline 5 & incs_dominant & 1.95 & .841 & $.54^{*}$ & $.53^{*}$ & $.63^{*}$ & $.60^{*}$ & 1 & & \\
\hline 6 & incs_sarcastic & 1.81 & .718 & $.49^{*}$ & $.42^{*}$ & $.52^{*}$ & $.37^{*}$ & $.65^{*}$ & 1 & \\
\hline 7 & grandiose & 1.37 & .853 & $.31^{*}$ & $.24^{*}$ & $.30^{*}$ & $.26^{*}$ & $.45^{*}$ & $.42^{*}$ & 1 \\
\hline 8 & aggression & 1.90 & .454 & $.59^{*}$ & $.39^{*}$ & $.49^{*}$ & $.35^{*}$ & $.64^{*}$ & $.54^{*}$ & .35 \\
\hline
\end{tabular}


factor loadings are shown in Table 2.

\section{Preliminary Analysis}

The results of the Confirmatory Factor Analysis (CFA) and goodness-of-fit statistics show that the data fit the model well. The item loadings of latent variables range between .45 and .99 . Results of the CFA indicate that each indicator variable and its respective variable are related. These results attest to a relationship between indicators and constructs, and thus validity is proven (46). Goodness-of-fit indices are shown in the Table 3.

\section{Test of the Model}

The structural model is evaluated using standardized path coefficients, their significance level ( $t$ statistics) and $\mathrm{R}^{2}$ estimates. The $\mathrm{R}^{2}$ of negative communication style variables indicate that the exogenous variables explain significance variances of each (Table 4$). \mathrm{R}^{2}$ values should be greater than value of $.10(47)$.

In order to test the hypothesis, the structural model through which we tested direct and indirect effects was examined. As the correlations among the variables were significant, a mediating test was deemed appropriate for use on all results. The indirect effect was tested using a bootstrap estimation approach with 2000 samples (48). The results support all hypotheses in attesting to aggression as a full mediator between grandiose narcissistic features and negative communication styles. Grandiose narcissistic features are not a significant predictor after controlling for the mediator, aggression, consistent with full mediation. The direct and indirect path coefficients are shown in the Table 5.

The values shown in the table assert that aggression plays a mediating role between grandiose narcissistic features and negative communication styles,
Table 2. T-Values and Factor Loadings

\begin{tabular}{lcc}
\hline Construct and Indicators & Factor loading & t-value \\
\hline Grandiose Narcissism & & \\
\hline Superiority & 0,830 & \\
\hline Exhibitionism, & 0,752 & 21,300 \\
\hline Self-sufficiency & 0,958 & 32,359 \\
\hline Authority & 0,989 & 34,009 \\
\hline Entitlement & 0,560 & 14,640 \\
\hline Aggression & & \\
\hline Hostility & 0,452 & 9,729 \\
\hline Physical Aggression & 0,712 & 14,306 \\
\hline Verbal Aggression & 0,637 & \\
\hline
\end{tabular}

leaving little doubt that narcissism indeed brings about aggression toward others, thereby transforming communication styles into a negative.

\section{DISCUSSION}

In this study, associations between narcissistic characteristics, aggression, and negative interpersonal communication styles were examined as a whole model from a sample of Turkish university students. The results showed that people with grandiose narcissism characteristics significantly predict negative communication styles. After controlling aggression, this is no longer a significant predictor of interpersonal style that means full mediation effect of aggression in this relationship. Thus, aggression mediates the relationship between grandiose narcissistic characteristics and negative interpersonal communication styles (dominant, avoidance, aggressiveness, insensitive, manipulative, and sarcastic). The significant mediation effect of aggression implies that narcissistic characteristics bring aggression toward other people that ultimately leads negative manners of contact with others.

The results of the current study follow in line with the relevant literature. Many previous studies have revealed that people with grandiose narcissistic character traits display more aggressive behavior than others $(13,21,23,22,24)$. These aggressive traits, in turn, may relate to problems with inter-

Table 3. Goodness-of-fit Indices

\begin{tabular}{lccccccc}
\hline & $\mathrm{x}^{2}$ & $\mathrm{df}$ & $\mathrm{CFI}$ & $\mathrm{TLI}$ & GFI & RMSEA & SRMR \\
\hline Measurement Model & 180.801 & 54 & .976 & .959 & .958 & .064 & .051 \\
\hline Structural Model & 259.405 & 65 & .963 & .948 & .941 & .072 & .055 \\
\hline Reference Values* & & & $>90$ & $>90$ & $>90$ & $<.08$ & $<.08$ \\
\hline *Values are according to Hu and Bentler (1999) & & & & &
\end{tabular}


Table 4. $\mathrm{R}^{2}$ Values

\begin{tabular}{lc}
\hline Variables & $\mathrm{R}^{2}$ \\
\hline Aggression & 0,258 \\
incs_aggressive & 0,466 \\
incs_manipulative & 0,343 \\
incs_avoidant & 0,474 \\
incs_insensitive & 0,236 \\
incs_dominant & 0,727 \\
incs_sarcastic & 0,546 \\
\hline
\end{tabular}

incs: interpersonal negative communication style

personal functioning. Grandiose narcissism includes intra-psychic processes such as suppressing negative sides of self and distorting disconfirming external information, leading to entitlement and an inflated self-image and prevailing sense of superiority. Such grandiosity is typically expressed through interpersonally exploitative acts, lack of empathy, intense envy, aggression, and exhibitionism (49). Some other researchers also agree that narcissism is associated with hostility toward others, dominance, and intrusiveness in relationships $(9,21)$. Within the clinical literature, many researchers have tried to explain how narcissism impairs interpersonal relationships. For those with narcissistic features, interpersonal relationships are used to support a self that cannot maintain a sense of well-being internally (50). These people are inclined to build self-esteem through domination of others, intimidating demands, denigration of others for not meeting expectations, and devaluation of people that threaten their sense of superiority $(51,52,53)$. Therefore, interpersonal exploitation and exhibitionism help to create an illusive sense of self-importance. Robbins and Dupont (54) point out that the relationship among narcissism, aggression, and interpersonal difficulties is a vicious cycle. Maladaptive interpersonal behavior by people with narcissistic features results in a breakdown of social relations, which bolsters a fragile sense of self. This, in turn, causes them to regulate their self-esteem through building interpersonal relations of a domineering/vindictive nature. Thus, the findings of the present study that confirm the mediating role of aggression that causes grandiose narcissism to surface in negative interpersonal relationships are parallel with previous findings. That is to say, people with grandiose narcissistic character traits show more aggression, and thus display of aggressive behavior which affects their communication with others.

On the other hand, aggression and negative interpersonal communication styles held as indicators of narcissism may also relate to personality pathology (e.g. borderline, antisocial) and not narcissism per se. Since personality disorders are strongly associated with interpersonal difficulties (55), the unique predictive power of narcissism in predicting negative interpersonal functioning requires more clarification by examining personality pathology.

This study has a number of limitations. First of all, reliance on self-report measures may cause social desirability effects in participants' response. In other words, participants may not have given honest answers to the questions in the survey. Thus, socially desirable responding may have affected the reliability of the results adversely. Secondly, female participants vastly outnumbered their male counterparts. Inequality of the gender distribution in the sample could mislead the results in terms of a possible gender effect which might have been attainable had the number of the two groups been

Table 5. The Direct and Indirect Path Coefficients

\begin{tabular}{llccc}
\hline Path & Direct Effect & Indirect Effect* & Total Effect \\
\hline Grandiose Narcissism > & Aggression & .51 & - & .51 \\
\hline Aggression > Anger & .69 & - & .69 \\
\hline Aggression > Dominant & .81 & - & .81 \\
\hline Aggression > Insensitive & .47 & - & .47 \\
\hline Aggression > Avoidant & .72 & - & .72 \\
\hline Aggression > Manipulative & .62 & - & .62 \\
\hline Aggression > Sarcastic & .68 & - & .68 \\
\hline Grandiose Narcissism > Anger & -.02 & .35 & .33 \\
\hline Grandiose Narcissism > & Dominant & .07 & .41 & .48 \\
\hline Grandiose Narcissism > Insensitive & .04 & .24 & .28 \\
\hline Grandiose Narcissism > & Avoidant & -.06 & .37 & .31 \\
\hline Grandiose Narcissism > & Manipulative & -.07 & .31 & .24 \\
\hline Grandiose Narcissism > Sarcastic & .10 & .35 & .45 \\
\hline
\end{tabular}

*Indirect Effect is through aggression using bootstrap estimation, 95\% 
equal. Another limitation is related to the generalizability of the results. Because most of the participants in this study were undergraduate students at a private university in Istanbul, the generalizability of the results to all university students is relatively low. Lastly, although the participants were asked to notify whether they had been diagnosed with any psychiatric disorders, no rating scales screening for psychopathology were used. This can be seen as a limitation since the results observed in the study may be a part of the psychopathology of the participants. Similarly, personality traits of the participants themselves were not examined within the scope of this study, and thus the results that seem to represent an aspect of narcissism may overlap with other personality traits (e.g. trait anger). These limitations should be gleaned when considering the results.

Despite these limitations, the present study may enrich the narcissism literature in several ways. Firstly, despite the fact that narcissism is very common-especially among young individuals worldwide (32)-the number of Turkish studies investigating narcissistic remain limited, so the current study may shed light on the interpersonal relationship of those with grandiose narcissistic characteristics in a uniquely Turkish cultural context. Secondly, the present study promotes a greater understanding of the possible mechanisms that lie behind the relationship difficulties people with grandiose narcissistic characteristics face. Thus, the results of the present study may inspire the field to develop more targeted interventionist treatments for relationship problems of this nature. The results show that people with narcissistic characteristics are apt to show disruptive behaviors and these behaviors cause difficulties in establishing and sustaining interpersonal relationships. In therapy, therapist can help their clients gain greater insight into the links between narcissistic features and negative interpersonal functioning. By raising awareness about the cyclic nature of this relationship, the client may understand the underlying reasons of interpersonal problems that they have. Identifying relationship patterns may help them to accept their role in interpersonal relationships and take responsibility of their own behaviors. Furthermore, it can be assumed that the relationship style of person with narcissistic features also emerges in therapeu- tic relationship. Thus, therapist should be aware of the communication style of both the client and themselves during sessions. Brandley and colleagues (56) found that many clinicians' accounts of counter-transference responses to patients with narcissistic personality disorder were typically characterized by the following responses: "I feel annoyed in sessions with him/her"; "I feel used or manipulated by him/her"; "I lose my temper with him/her"; "I feel mistreated or abused by him/her"; and "I feel resentful working with him/her". Being aware of the relationship style of the client and counter-transference responses may aid in attaining positive therapeutic progress. This awareness may also provide for useful material which would go some way towards identifying a patient's interpersonal style outside sessions in order to get on with the work of resolving these issues better during. In addition to gaining insight into the relationship patterns associated with narcissistic features, some cognitive and behavioral exercises such as anger management, effective communication and problem solving skills can be implemented in the intervention program since narcissistic features are associated with aggression and nonfunctional communication styles.

In future studies, both grandiose narcissism and vulnerable narcissism ought to be investigated in an integrative model regardless of whether the paths that explain these two dimensions of narcissism differ or not. In other words, by including vulnerable narcissism in future studies, it can be ascertained as to whether grandiose and vulnerable narcissistic personality characteristics are related to different interpersonal relationship styles with the mediation of different constructs. Furthermore, by equating the number of men and women participants, two separate models may be tested for men and women to see whether different models may exist in future studies. Finally, there is a great need to investigate narcissistic personality characteristics using clinical samples. Thus, these results may be tested against the clinical population of various age groups.

Correspondence address: Res.Asis.. Reyhan Arslan, Istanbul Medeniyet University, Faculty of Education, Department of Guidance and Psychological Counseling, Istanbul, Turkey reyhanarslan@medipol.edu.tr 


\section{REFERENCES}

1. Gentile B, Miller JD, Hoffman BJ, Reidy DE, Zeichner A. Campbell K. A test of two brief measures of grandiose narcissism: The narcissistic personality inventory-13 and the narcissistic personality inventory-16. Psychological Assessment 2013; 25:1120-1136.

2. Samuel DB, Widiger TA. Convergence of narcissism measures from the perspective of general personality functioning. Assessment 2008; 15:364-374.

3. Miller JD, Campbell WK. The case for using research on trait narcissism as a building block for understanding narcissistic personality disorder. Journal of Personality 2010; 1:180-191.

4. Campbell WK, Brunell AB, Finkel EJ. Narcissism, Interpersonal Self-Regulation, and Romantic Relationships: An Agency Model Approach. Edited by Finkel EJ, Vohs KD. New York, Guilford Press, 2006, pp. 57?83.

5. Foster JD, Campbell WK. Are there such things as "narcissists" in social psychology? A taxometric analysis of the Narcissistic Personality Inventory. Personality and Individual Differences 2007; 43:1321?1332.

6. Miller JD, Dir A, Gentile B, Wilson L, Pryor LR, Campbell WK. Searching for a vulnerable dark triad: Comparing factor 2 psychopathy, vulnerable narcissism, and borderline personality disorder. Journal of Personality 2010; 78:1529-1564.

7. Campbell WK, Hoffman BJ, Campbell SM, Marchisio, G. Narcissism in organizational context. Human Resource Management Review 2011; 21268-284.

8. Miller JD, Lynam DR, Campbell WK. Measures of narcissism and their relations to DSM-5 pathological traits: a critical reappraisal. Assessment 2016; 23:3-9.

9. Dickinson KA, Pincus AL. Interpersonal analysis of grandiose and vulnerable narcissism. Journal of Personality Disorders 2003; 17:188-207.

10. Pincus AL, Lukowitsky MR. Pathological narcissism and narcissistic personality disorder. Annual Review of Clinical Psychology 2010; 6:421-446.

11. Rose P. The happy and unhappy faces of narcissism. Personality and Individual Differences 2002; 33:379-391.

12. Besser A, Priel, B. Grandiose narcissism versus vulnerable narcissism in threatening situations: emotional reactions to achievement failure and interpersonal rejection. Journal of Social and Clinical Psychology 2010; 29:874-902.

13. Bushman BJ, Baumeister RF, Thomaes S, Ryu E, Begeer S, West SG. Looking again, and harder, for a link between low selfesteem and aggression. Journal of Personality 2009; 77:427- 446.

14. Given-Wilson Z, McIlwain D, Warburton W. Meta-cognitive and interpersonal difficulties in overt and covert narcissism. Personality and Individual Differences 2011; 50, 1000-1005.

15. Miller JD, Campbell WK. Comparing clinical and social-personality conceptualizations of narcissism. Journal of Personality 2008; 76:449? 476

16. Ronningstam E. Identifying and Understanding Narcissistic Personality. New York, Oxford University Press, 2005.

17. Schoenleber M, Sadeh N, Verona E. Parallel syndromes:
Two dimensions of narcissism and the facets of psychopathic personality in criminally involved individuals. Personality Disorders: Theory, Research, and Treatment 2011; 2:113-127.

18. Morf CC, Rhodewalt F. Unraveling the paradoxes of narcissism: A dynamic self-regulatory processing model. Psychological Inquiry 2001; 12:177-196.

19. Fossati A, Borroni S, Eisenberg N, Maffei C. Relations of proactive and reactive dimensions of aggression to grandiose and covert narcissism in nonclinical adolescents. Aggressive Behavior 2010; 36:21-27.

20. Lobbestael J, Baumeister RF, Fiebig T, Eckel LA. The role of grandiose and vulnerable narcissism in self-reported and laboratory aggression and testosterone reactivity. Personality and Individual Differences 2014; 69:22-27.

21. Bushman BJ, Baumeister RF. Threatened egotism, narcissism, self-esteem, and direct and displaced aggression: Does self-love or self-hate lead to violence? Journal of Personality and Social Psychology 1998; 75:219-229.

22. Twenge JM, Campbell WK. "Isn't it fun to get the respect that we're going to deserve?" Narcissism, social rejection, and aggression. Personality and Social Psychology Bulletin 2003; 29:261-272.

23. Ronningstam E. Narcissistic personality disorder: Facing DSM-V. Psychiatric Annuals 2009; 39:111-121.

24. Campbell WK, Foster CA. Narcissism and commitment in romantic relationships: an investment model analysis. Personality and Social Psychology Bulletin 2002; 28:484-495.

25. Buss AH, Perry M. The Aggression Questionnaire. Journal of Personality and Social Psychology 1992; 63:452-459.

26. Hollister-Wagner GH, Foshee V, Jackson C. Adolescent aggression: Models of resiliency. Journal of Applied Social Psychology 2001; 31:445-466.

27. Steiner H, Saxena K, Chang K. Psychopharmacologic strategies for the treatment of aggression in juveniles. CNS Spectrum 2003; 8:298-308

28. Washburn JJ, McMahon SD, King CA, Reinecke MA, Silver C. Narcissistic features in young adolescents: Relations to aggression and internalizing symptoms. Journal of Youth and Adolescence 2004; 33:247-260.

29. Evans M, Heriot SA, Friedman AG. A behavioral pattern of irritability, hostility and inhibited empathy in children. Clinical Child Psychology and Psychiatry 2002; 7:211-22.

30. Barry CT, Frick PJ, Killian AL. The relation of narcissism and self-esteem to conduct problems in children: A preliminary investigation. Journal of Clinical Child Adolescent Psychology 2003; 32:139-152.

31. Barry TD, Thompson A, Barry CT, Lochman JE, Adler K, Hill K. The importance of narcissism in predicting proactive and reactive aggression in moderately to highly aggressive children. Aggressive Behavior 2007; 33:185-197.

32. Stinson FS, Dawson DA, Goldstein RB, Chou SP, Huang B, Smith SM, Ruan WJ, Pulay AJ, Saha TD, Pickering RP, Grant BF. Prevalence, correlates, disability, and comorbidity of DSM- 
The role of aggression in the relationship between grandiose narcissistic traits and interpersonal style: University students in Turkey

IV narcissistic personality disorder: results from the Wave 2 National Epidemiologic Survey on Alcohol and Related Conditions. Journal of Clinical Psychiatry 2008; 69:1033-45.

33. Ames DR, Rose P, Anderson CP. The NPI-16 as a short measure of narcissism. Journal of Research in Personality 2016; 40:440-450.

34. Atay S. Narsistik Kişilik Envanteri'nin Türkçe'ye Standardizasyonu. Gazi Üniversitesi İktisadi ve İdari Bilimler Fakültesi Dergisi 2009; 11:181-196.

35. Demirtaş-Madran HA. Buss Perry Saldırganlık Ölçeğinin Türkçe Formunun Geçerlik ve Güvenirlik Çalışması. Türk Psikiyatri Dergisi 2012; 23:1-6.

36. Balkaya F, Şahin NH. Çok Boyutlu Öfke Ölçeği. Türk Psikiyatri Dergisi 2003; 14:192-202.

37. Şahin NH, Çeri Ö, Düzgün G, Ergün H, Karslı E, Koç V, Örflü P, Uzun C. (2007). Kişilerarası Tarz Ölçeği. Ankara: Yayımlanmamış Çalışma.

38. Bollen KA. A new incremental fit index for general structural equation models. Sociological Methods \& Research 1989; 17:303-316.

39. Joreskog KG, Sörbom D. New Features in LISREL 8. Chicago, Scientific Software, 1993.

40. Kline RB. Software review: Software programs for structural equation modeling: Amos, EQS, and LISREL. Journal of Psychoeducational Assessment 1998; 16:343-364.

41. Preacher KJ, Hayes AF. SPSS and SAS procedures for estimating indirect effects in simple mediation models. Behavior Research Methods, Instruments \& Computers 2004; 36:717-731.

42. Little TD, Cunningham WA, Shahar G, Widaman KF. To parcel or not to parcel: Exploring the question, weighing the merits. Structural Equation Modeling 2002; 9:151-173.

43. Chin WW, Gopal A, Salisbury, WD. Advancing the theory of adaptive structuration: The development of a scale to measure faithfulness of appropriation. Information systems research 1997; 8:342-367.

44. Fornell C, Larcker DF. Structural equation models with unobservable variables and measurement error: Algebra and statistics. Journal of Marketing Research 1981; 18:382-388.

45. Wixom BH, Watson HJ. An empirical investigation of the factors affecting data warehousing success. MIS Quarterly 2001; 25:17-41.

46. Hair JF, Anderson RE, Tatham RL, Black WC. Multivariate Data Analysis. New Jersey, Englewood Cliff, 1998.

47. Falk RF, Miller NB. A Primer for Soft Modeling. United States, University of Akron Press, 1992.

48. Shrout PE, Bolger N. Mediation in experimental and nonexperimental studies: New procedures and recommendations. Psychological Methods 2002; 7:422-445.

49. Pincus AL, Ansell EB, Pimentel CA, Cain NM, Wright AGC, Levy KN. Initial construction and validation of the Pathological Narcissism Inventory. Psychological Assessment 2009; 21:365379 .

50. Kohut H. How Does Analysis Cure Chicago, University of
Chicago Press, 1984.

51. Campbell WK, Baumeister RF. Narcissistic personality disorder. In: Fisher JE, O'Donohue WT, editors. Practitioner's Guide to Evidence-Based Psychotherapy. New York: Springer, 2006, pp. 423-31.

52. Gabbard GO. Transference and countertransference in the treatment of narcissistic patients. In: Ronningstam E, editor. Disorders of Narcissism: Diagnostic, Clinical, and Empirical Implications. Washington (DC), American Psychiatric Press, 1998, pp. 125-46.

53. Millon T, Davis RD. Disorders of Personality: DSM-IV and Beyond. New York, Wiley, 1996.

54. Robbins SB, Dupont P. Narcissistic needs of the self and perceptions of interpersonal behaviour. Journal of Counseling Psychology 1992; 39:462-7.

55. Johnson JG, First MB, Cohen P, Skodol AE, Kasen S, Brook JS. Adverse outcomes associated with personality disorder not otherwise specified in a community sample. American Journal of Psychiatry 2005; 162:1926-32.

56. Bradley R, Heim AK, Westen D. Transference patterns in the psychotherapy of personality disorders: empirical investigation. British Journal of Psychiatry 2005; 186:342-9. 